\title{
ЦЕНТРАЛЬНАЯ АЗИЯ
}

\author{
ВКЛАД РОССИИ \\ В РЕГИОНАЛЬНОЕ \\ СОТРУДНИЧЕСТВО В СФЕРЕ \\ БЕЗОПАСНОСТИ
}

Чернявский С.И.

В статье анализируется состояние военно-политического сотрудниества России с государствами Центральной Азии на двусторонней основе и в формате Организации Договора о коллктивной безопасности.

есмотря на целенаправленные усилия полиТического руководства, центральноазиатский вектор внешней политики России пока не принес ожидаемых результатов. Как нам представляется, во многом это связано с тем, что Российская Федерация все еще не в состоянии предложить региону собственный, специфический вариант развития, радикально отличающийся от тех, которые предлагают страны Евросоюза, АТР или исламского мира. Возможности России использовать здесь «мягкую силу» ограничены и сводятся, как правило, к опоре на позитивные элементы советского прошлого ${ }^{1}$.

Если рассматривать гипотетически некий идеальный вариант развития событий, то интересам России соответствовало бы сохранение этого региона внутри постсоветского пространства с постепенным усилением в нем центростремительных сил и ослаблением центробежных. При этом важным фактором была бы нейтрализация попыток стереть сконструированные в интересах СССР границы между Центральной Азией, АТР и исламским миром, что активно пытаются сделать такие внешние игроки как исламские государства и Китай. Россия также пытается не допустить самостоятельный доступ центральноазиатских стран в Европу, стремясь сохранить за собой роль традиционного посредника между Европой и Центральной Азией во всех сферах ${ }^{2}$.

Однако попытки реализации вышеуказанных задач сталкиваются как с объективными трудностями, привнесенными глобализацией, так и с местными особенностями развитияз . Глобализация как бы вновь «открыла» этот замкнутый в течение нескольких столетий Афганистаном, Ираном, Китаем и Россией регион для остального мира. Появилось большое количество новых акторов, обладающих значительным финансовым и военно-политическим потенциалом4. Что касается местной специфики, то ее главная отличительная черта - наблюдающаяся, к сожалению, в отдельных странах монополизация власти узким кругом лиц, семейно-клановый состав правящей элиты, безудержное стремление к культу личности руководителя5.

С учетом специфики географического расположения и социально-политического развития

Чернявский Станислав Иванович - доктор исторических наук, директор Центра постсоветских исследований ИМИ МГИМО (У) МИД РФ, e-mail: ktsmi@mgimo.ru. 
Чернявский С.И.

региона было бы оправданным разделить существующие угрозы национальной безопасности на три категории - глобальные, региональные и внутригосударственные.

В глобальной плоскости источником угроз для всех новых государств региона является процесс формирования нового мирового порядка и новой геополитической конфигурации, происходящий передел сфер влияния и возрастание конкуренции мировых центров силы.

В региональной плоскости важным дестабилизирующим фактором является перманентно кризисная социально-политическая и социальноэкономическая ситуация. Не соответствующие реалиям политические и экономические преобразования постсоветского периода привели к обнищанию основной массы населения региона, что, помимо иного, является одной из основных причин активизации деятельности ряда экстремистских и террористических организаций.

Во внутригосударственной плоскости вероятными причинами возникновения войн и вооруженных конфликтов могут стать следующие.

1. Межэтнические проблемы, обусловленные несоответствием существующих границ реальному национально-территориальному размещению населения. Во всех государствах региона, существуют значительные по численности диаспоры этнических представителей сопредельных стран. При этом этнические диаспоры сосредоточены главным образом в приграничных районах.

2. Сепаратизм на социально-экономической почве. Более низкий по сравнению с соседними государствами (Казахстан, Узбекистан) жизненный уровень в Киргизии и Таджикистане может породить стремление национальных меньшинств в приграничных районах к территориальному воссоединению с этнической родиной или сепаратизм.

3. Сепаратизм вследствие ущемления прав национальных меньшинств (применительно к Киргизии и Таджикистану это относится в основном к узбекской этнической общине).

4. Сепаратизм из-за географической разобщенности территорий внутри государств региона. В частности, Ошская и Джалал-Абадская области Киргизии отделены Ферганским хребтом от остальной части страны. Их территориально-экономическая обособленность усиливается этническим фактором.

5. Борьба за власть между различными политическими силами, имеющая потенциал перерастания в вооруженный конфликт.

Имеющиеся экономические, человеческие, военные и иные ресурсы не позволяют государствам
Центральной Азии эффективно противодействовать всему спектру угроз безопасности и угроз военного характера6.

Высокая региональная неопределенность и нестабильность создают серьезные препятствия для конкретизации и повышения эффективности политики России в Центральной Азии. Ее важнейшим элементом остается сотрудничество в вопросах безопасности, в чем практически в равной степени заинтересованы как государства региона, так и российская сторона7.

Военно-политическое взаимодействие реализуется как на двусторонней, так и на многосторонней основе (в рамках Организации Договора о коллективной безопасности, в первую очередь).

Рассмотрим, прежде всего, состояние и перспективы двустороннего военно-политического взаимодействия.

В развитии двустороннего сотрудничества российская сторона стремится придерживаться равного подхода ко всем государствам региона, хотя на практике наиболее интенсивное взаимодействие в вопросах безопасности реализуется в отношениях с Республикой Казахстан.

РЕСПУБЛИКА КАЗАХСТАН является основным военно-политическим и экономическим партнером России в Центральной Азии. Двусторонние связи отличаются интенсивностью контактов на высшем и высоком уровнях, активным многоплановым сотрудничеством, солидной договорноправовой базой. Новым вкладом в развитие российско-казахстанского взаимодействия стала недавняя встреча президентов Д.А. Медведева и Н.А. Назарбаева на Форуме делового сотрудничества России и Казахстана 11 сентября 2009 г. в Оренбурге.

Стратегический характер российско-казахстанских отношений определяется геополитическим положением Казахстана, в том числе в каспийском регионе, его крупным экономическим и сырьевым потенциалом, значением для нас уникального космодрома «Байконур», наличием в стране более 4-миллионной диаспоры русского населения.

Казахстан стал первым государством СНГ, заключившим с Россией в мае 1992 г. Договор «О дружбе, сотрудничестве и взаимной помощи». Согласно этому Договору предусматривается создание общего военно-стратегического пространства, совместное использование военных баз, полигонов и иных военных объектов в случае угрозы России или Казахстану.

С момента обретения Казахстаном независимости между силовыми ведомствами обоих государств установились партнерские связи, 


\section{Международные отношения}

характеризующиеся регулярными рабочими встречами на различных уровнях, выработкой единых подходов к ряду вопросов, представляющих взаимный интерес в сфере безопасности и военного сотрудничества. На уровне министерств и ведомств силового блока регулярно разрабатываются и вносятся дополнения и поправки к уже достигнутым соглашениям.

Знаковым событием военного взаимодействия стало подписание в январе 2004 г. соглашения между Министерством обороны России и Министерством обороны Казахстана по вопросам совместного планирования применения войск (сил) в интересах обеспечения национальной безопасности двух стран.

С целью отработки алгоритма совместных действий на регулярной основе проводятся учения с привлечением частей и подразделений российской и казахстанской армии, причем, как в рамках мероприятий в формате ОДКБ и ШОС, так и на двусторонней основе.

Между военными ведомствами России и Казахстана достигнуто соглашение на период с 2009 по 2011 гг. о ежегодном проведении совместных военных учений на территории двух государств поочередно.

В качестве примера приведу проведенные в первой декаде июля 2008 г. в учебном центре сухопутных войск ВС Казахстана в поселке Гвардейский близ Алматы российско-казахстанские учения «Взаимодействие-2008» с участием более 2 тысяч российских и казахстанских десантников, свыше 40 единиц самолетов и вертолетов, более 240 единиц боевой техники. В период с конца августа по 27 сентября 2008 г. в соответствии с планом подготовки Сухопутных войск РФ проводились оперативно-стратегические учения с войсками Приволжско-Уральского военного округа «Центр-2008», на отдельных этапах которых отрабатывались совместные действия подразделений вооруженных сил России и Казахстана, в том числе мероприятия по антитеррору. Тактические занятия с боевой стрельбой российских и казахстанских подразделений проходили и в текущем году.

На основании соглашения, подписанного в 1995 г., Россия и Казахстан предпринимают совместные усилия по обеспечению безопасности казахстанской границы по внешнему периметру. Взаимодействие заключается в постоянном о6мене информацией об обстановке, складывающейся на границе, в пунктах пропуска и по другим направлениям деятельности пограничных войск. Пограничные ведомства двух стран регулярно отрабатывают и проводят совместные специальные операции, нацеленные на выявление и пресечение каналов незаконного оборота наркотиков и нелегальной миграции, особенно в северной части Каспийского моря и на китайском направлении.

Что касается вопросов военно-технического сотрудничества, то ими занимается созданная в январе 2001 г. двусторонняя комиссия. Россия поставляет Казахстану современное вооружение и военную технику, запасные части и комплектующие на льготных условиях - по российским внутригосударственным ценам.

В 2006 г. подписан контракт на поставку Россией Казахстану в период 2007-2008 гг. 80 бронетранспортеров БТР-8о на сумму около $20 \mathrm{Mлн}$ долларов. В конце 2006 г. Россия заключила соглашение с Казахстаном о поставках по льготным ценам 12 многоцелевых вертолетов Ми-17 и легких АНСАТ, предназначенных для пополнения парка армейской авиации национальных ВС.

Кроме того, на состоявшемся в августе 2007 г. авиасалоне МАКС российскими и казахстанскими представителями были подписаны новые контрактные документы на сумму более 60 млн долларов. Согласно достигнутым договоренностям, в г. Ржеве (Россия) будет производиться ремонт и модернизация 10 самолетов МиГ-31, МиГ-29 и Су-25, составляющих основу авиационного парка ВВС Казахстана. В контрактах оговорена также поставка современных тренажеров и оборудования для подготовки летчиков.

Важным элементом участия России в реформировании казахстанского сектора безопасности является подготовка в России казахстанских военнослужащих для силовых структур Казахстана. Подготовка в военно-учебных заведениях РФ основана на Договоре «О военном сотрудничестве» и Соглашении стран-участников СНГ «О развитии сотрудничества в области подготовки военных кадров», подписанного 6 марта 1998 г. В рамках этих договоренностей само обучение является бесплатным, а содержание военнослужащих осуществляется за счет направляющей стороны.

За период 1993-2008гг. в высших учебных заведениях (ВУЗах) Министерства обороны и других силовых структур России прошли обучение около 3 тысяч граждан Казахстана, что составляет примерно треть от общего количества граждан стран СНГ, получивших военное и специальное образование в России. Обучение казахстанских граждан проводится по единым с российскими военнослужащими программам на основе современных военно-доктринальных разработок. Специалисты, обучающиеся в военных ВУЗах России, удовлетворяют потребности казахстанских 
Чернявский С.И.

Вооруженных сил как с точки зрения методики обучения, так и уровня подготовки.

Начиная с 2003 г., к учебному процессу в Национальном университете обороны Казахстана на регулярной основе привлекается профессорскопреподавательский состав российских высших военно-учебных заведений. Особое внимание в последние годы Казахстан стал уделять подготовке в российских военно-учебных заведениях офицеров по космическим специальностям.

С РЕСПУБЛИКОЙ УЗБЕКИСТАН, несмотря на отдельные проблемы, ожидающие своего решения, также осуществляется взаимовыгодное сотрудничество в реформировании сектора безопасности. Эта работа ведется на основе Догово-

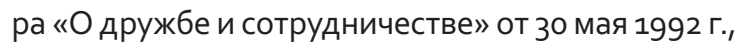
Соглашения «О принципах взаимного технического и материального обеспечения вооруженных сил» от 2 марта 1994 г., Договора «О дальнейшем углублении всестороннего сотрудничества в военной и военно-технической областях» от 11 декабря 1999 г., Договора «О стратегическом партнерстве» от 16 июня 2004 г., а также Договора «О союзнических отношениях» от 14 ноября 2005 г.

В силу своего геополитического, экономического, демографического и военного потенциала Узбекистан объективно является ключевым государством региона. Он располагает наиболее боеспособными и хорошо оснащенными в регионе вооруженными силами, которые имеют непосредственный боевой опыт ведения специальных операций в горных условиях.

В отличие от других центральноазиатских государств, узбекские вооруженные силы крайне редко принимают непосредственное участие в совместных с российскими подразделениями учениях.

Первые совместные тактические учения спецподразделений ВС России и Узбекистана, в которых приняли участие 200 российских военнослужащих из состава спецподразделений ГРУ ГШ ВС РФ, а с узбекской стороны - ряд подразделений и артиллерийские расчеты проводились в 2005 г. на узбекском горном полигоне «Фариш» (Джизакская область). Кроме подразделений узбекского горного спецназа в них участвовали российские вертолетчики на Ми-8 и Ми-24. Учения аналогичного профиля «Боевое братство-2006» в 2006 г. прошли на полигоне Северокавказского военного округа России (Краснодарский край).

В конце 2007 г. военные ведомства двух стран достигли соглашения о ежегодных, начиная с 2008 г., совместных тренировках специалистов ПВО и ВВС на российском полигоне «Ашулук» (Астраханская область).
В связи с активизацией деятельности формирований исламских радикалов узбекская армия, в первую очередь, специальные подразделения, стали испытывать нехватку современного стрелкового вооружения. В декабре 1999 г. в ходе официального визита в Узбекистан премьер-министра России В.В. Путина был подписан Договор «О дальнейшем углублении сотрудничества в военной и военно-технической областях», который наряду с более тесным взаимодействием между министерствами обороны и вооруженными силами двух стран по вопросам укрепления безопасности и совместной борьбы с международным терроризмом, предусматривал увеличение ассортимента военной продукции, поставляемой из РФ. В соответствии с указанным договором в Узбекистан было поставлено необходимое вооружение, в первую очередь автоматы, снайперские винтовки, ручные пулеметы и приборы ночного видения.

В последнее время номенклатура и объемы поставляемой продукции военного назначения значительно выросли. На конец 2008 г., по оценкам российского министерства обороны, объем военно-технического сотрудничества с Узбекистаном достиг нескольких десятков миллионов долларов. Речь идет преимущественно о поставках современного стрелкового вооружения, боеприпасов, запчастей к бронетанковой технике, средств ПВО, а также ремонте авиатехники.

Россия принимает участие в подготовке военных кадров для Узбекистана. Начиная с 1992 г., в военных ВУЗах и специализированных заведениях РФ подготовлено около 350 узбекских офицеров. По сравнению с другими государствами ЦА, такое незначительное количество объясняется тем, что в Узбекистан сам располагает многочисленной сетью военно-учебных заведений, в том числе двумя академиями (ВС и МВД), а также частично готовил офицеров по отдельным специальностям в странах дальнего зарубежья.

В ходе государственного визита Президента России Д.А. Медведева в Ташкент 22-23 января 2009 г. российская сторона подчеркивала, что «для насУзбекистан - ключевой, стратегический партнер в Средней Азии. И ценим то сотрудничество, которое мы осуществляем в сфере безопасности, обеспечения правопорядка в этом важнейшем регионе».

Еще одна пограничная с Россией страна ТУРКМЕНИСТАН.

Российское участие в реформировании туркменского сектора безопасности носит ограниченный характер, поскольку в последние 1015 лет Туркмения в области военного и военно-технического сотрудничества переориентировалась 


\section{Международные отношения}

в основном на страны НАТО, Пакистан и Китай. Ашхабад диверсифицировал поставки вооружений и военной техники, практически отказавшись от услуг российского оборонного промышленного комплекса ${ }^{8}$.

Однако туркменские зенитные ракетные комплексы С-6o, «ОСА-АКМ», «Стрела-10», системы залпового огня «Ураган», «Град», минометы, самолеты-штурмовики МиГ-29 и СУ-25, вертолеты Ми-24 и Ми-8 уже давно требуют модернизации и ремонта, а помочь в этом Туркмении сможет только Россия. Первым шагом в этом направлении стала закупка Туркменией в 2008 г. шести комплексов реактивных систем залпового огня "Смерч».

В январе 2009 г. Президент Гурбангулы Бердымухаммедов утвердил своим указом новую Военную доктрину. Он осуществил ротацию всех силовых руководителей страны и лично участвует в совершенствовании боевого мастерства туркменской армии. Так, в начале марта текущего года он наблюдал за ходом показательных тактических учений с боевой стрельбой «Юг-2009», которые прошли неподалеку от Серхетабата (бывший город Кушка).

Обращает на себя внимание замысел учений, напрямую связанный с ситуацией в Афганистане. Как сообщают официальные туркменские источники, «согласно условной ситуации антиправительственная группировка, предпринявшая неудачную попытку вооруженного захвата власти в соседней стране, пересекает условную границу Туркмении и проникает на ее территорию с грузом наркотиков и оружия. С учетом возросшей опасности принимается решение отсечь вторгшегося противника от границы, окружить и предложить ему сложить оружие. После полученного отказа войска Туркмении приступают к проведению операции по уничтожению экстремистски настроенных вооруженных формирований. Положение на государственной границе восстанавливается».

Такой сценарий учений и действия войск выглядят закономерными, если учесть, что туркменские войска в сентябре 2008 г. уже реально воевали с террористической группировкой. Тогда погибли несколько десятков сотрудников спецслужб и военных.

Что касается подготовки военных кадров, по словам эксперта, здесь Ашхабад давно отдает предпочтение таким странам, какТурция и Пакистан. Из порядка 500 военных специалистов, направленных на учебу за рубеж, 200 человек обучаются в военно-учебных заведениях Турции, 200 - Пакистана, и только $6 о$ человек - в вузах России и Украины.

Несколько слов о тех центрально-азиатских государствах, которые ныне не являются непосредственными соседями России.
КЫРГЫЗСКАЯ РЕСПУБЛИКА. Российская политика в отношении Киргизии направлена на то, чтобы усиливать степень взаимодействия с ее силовыми структурами в сфере безопасности, военного и военно-технического сотрудничества9. О6 этом, в том числе, говорилось на встрече президентов Д.А. Медведева и К. Бакиева, проходившей в рамках саммита СНГ в Бишкеке 10 октября 2008 г.

23 октября 2003 г. начала функционировать российская авиабаза в Канте - первый после распада СССР военный объект РФ на территории иностранного государства. Военный аэродром Кант, расположенный в 20 км к востоку от Бишкека, один из двух киргизских аэродромов, пригодных для размещения боевых самолетов. Первый международный аэропорт Манас - в настоящее время занят силами международной антитеррористической коалиции

В советское время на аэродроме Кант располагалась база Центральных курсов подготовки летного состава Военно-воздушных сил. Здесь готовили иностранных курсантов для армий 34 стран мира. В Канте освоили профессию военного летчика президент Египта Хосни Мубарак, бывший президент Сирии Хафез Асад, летчики-космонавты из Монголии и Индии - Ракеш Шарма, маршал авиации Индии Синг.

Подписанное соглашение о статусе и условиях пребывания российской авиационной базы на территории Киргизии будет действовать в течение 15 лет и автоматически может продлеваться на последующие 5-летние периоды. Предполагается, что на киргизской авиабазе будут находиться до 500 российских военнослужащих и базироваться около 20 летательных аппаратов самолеты Су-25, Су-27, Ан-26, вертолеты Ми-8.

В апреле 2009 г. российская сторона заявила, что намерена расширить свое присутствие в Канте. По словам генерального секретаря Организации договора о коллективной безопасности (ОДКБ) Николая Бордюжи, предусмотрено увеличение количества самолетов, которые находятся на территории авиабазы.

Среди центрально-азиатских стран, которым оказывается помощь со стороны России в реформировании сектора безопасности особое место занимает РЕСПУБЛИКА ТАДЖИКИСТАН.

Ситуация вокруг границ этой горной республики остается сложной в связи с непосредственной близостью Афганистана. Поэтому ее расходы на оборону весьма значительны и продолжают расти. Если в 2005 г. они составляли 32,3 млн долл., то в 2008 г. выросли на 95\%, достигнув 63 млн долл. 
Чернявский С.И.

В 2006-2007 гг. Россия предоставила этой стране безвозмездную военную помощь на сумму более 1,5 млрд долл.

В Таджикистане расположена российская военная база, созданная в 2005 году на основе 201-й мотострелковой дивизии, дислоцированной в республике с 1993 г. На базе служат около 6 тысяч российских военных, базируются около 450 танков, БТР и БМП, зенитные установки и ракетные комплексы «Игла», а также штурмовики Су-25 и вертолеты Ми-24 и Ми-8. Части и подразделения базы дислоцируются в городах Душанбе, Куляб и Курган-Тюбе.

Кстати, именно 201-я российская военная мотострелковая дивизия в годы гражданской войны (1992-1996) в Таджикистане принимала активное участие в наведении конституционного порядка и оказывала военно-техническую помощь правительственным силам.

До настоящего времени Россия согласно взаимным договоренностям пользуется 201-й военной базой бесплатно. Однако таджикистанская сторона выдвинула ряд предложений по корректировке финансовых обязательств России по функционированию базы, а также подписанному в 2008 г. и до сих пор не реализованному соглашению об использовании Россией таджикского аэродрома «Айни».

ОСНОВНОЙ ФОРМАТ МНОГОСТОРОННЕГО ВОЕННО-ПОЛИТИЧЕСКОГО СОТРУДНИЧЕСТВА России с государствами Центральной Азии - Организация Договора о коллективной безопасности (ОДКБ), членами которой являются Россия, Армения, Белоруссия, Казахстан, Киргизия, Таджикистан и Узбекистан ${ }^{10}$.

Первые три года после заключения Ташкентского договора еще сохранялась надежда на то, что вместо могучей военной машины Советского Союза удастся создать нечто подобное. Руководство ДКБ рассчитывало преодолеть национальный эгоизм и общими усилиями сформировать новую эффективную систему региональной безопасности, которая включала бы и объединенные военные группировки. Но, увы, этим планам не суждено было сбыться. Не помогло даже то обстоятельство, что ряд членов ДКБ столкнулись с вполне явной военной угрозой своему суверенитету. Угрозой, с которой эти страны не смогли справиться в одиночку. Так во время «баткентских войн» малочисленный (всего несколько десятков штыков) отряд исламистских боевиков сумел нагнать страху на целое государство - Киргизию, армия которой умудрилась допустить пленение своего министра обороны.
Структуры военно-политического сотрудничества на постсоветском пространстве постоянно изменяли детали в основополагающих чертежах. Менялись состав участников, отдельные приоритеты сотрудничества и даже само название региональной структуры. С мая 2002 года она стала именоваться Организацией Договора о коллективной безопасности. После этого был определенный период (2004-2007 годы), когда руководство этой организации стало склоняться к идее реформирования ее в многофункциональную структуру.

ОДКБ стал заниматься и составлением списков террористических организаций, и борьбой с наркотрафиком, и борьбой с нелегальной миграцией, и предупреждением стихийных бедствий. Сфера военного сотрудничества ради укрепления совместной обороноспособности де-факто перестала быть доминирующей. Политический компонент явно превалировал над военным.

Но события августа 2008 года заставили руководство ряда государств-членов ОДКБ трезвее оценить ситуацию. Военная угроза, несмотря на все разговоры политиков о приверженности миру и бесконфликтному развитию, не перестала быть реальной.

Поэтому к саммиту ОДКБ, проходившему 14 июня 2009 г. в Москве, постарались подготовиться более квалифицированно, чем раньше. В результате на нем принято решение о создании Коллективных сил оперативного реагирования единой, высокопрофессиональной и боеспособной группировки ОДКБ.

Предполагается, что костяк Коллективных сил оперативного реагирования (КСОР) составят 98я Тульская гвардейская воздушно-десантная дивизия и 31-я гвардейская десантно-штурмовая бригада, базирующаяся в Ульяновске, - вместе около 10 тыс. человек. Из других участников Казахстан выразил готовность делегировать одну десантноштурмовую бригаду численностью примерно 34 тыс. человек. Остальные члены ОДКБ согласились предоставить по батальону различных сил, в каждый из которых войдет примерно 400$8 о 0$ человек. Таким образом, общая численность КСОР составит примерно 15 тыс. человек.

Создаются также силы специального назначения КСОР - подразделения спецназа органов внутренних дел (полиции), внутренних войск, органов безопасности и специальных служ6, а также органов, уполномоченных в сфере предупреждения и ликвидации последствий чрезвычайных ситуаций. В частности, от России в СПН КСОР предлагается включить отряд милиции особого назначения «Зубр» и отряд милиции специального назначения 


\section{Международные отношения}

«Рысь», от Белоруссии - специальный отряд быстрого реагирования бригады спецназначения Внутренних войск МВД республики, от Киргизиитакже специальный отряд быстрого реагирования МВД. Свои подразделения в Коллективные силы предоставят также органы безопасности и органы предупреждения и ликвидации последствий чрезвычайных ситуаций. МЧС России, например, предложило свой лучший отряд «Лидер», подготовленный для работы в любой точке мира.

Известно, что пока еще не все члены ОДКБ согласились с созданием КСОР - при особом мнении остался президент Узбекистана Ислам Каримов, заявивший, что войска его республики не войдут в Коллективные силы на постоянной основе, а будут присоединяться к ним в случае необходимости, президент Белоруссии А. Лукашенко также не торопился с подписанием соответствующих документов.

Каковы возражения Узбекистана?

Ташкент хотел бы, чтобы решения по применению КСОР принимались не большинством голосов, а консенсусом, то есть только единогласно. Также Узбекистан требует исключить ситуацию участия сил КСОР, если конфликт произойдет между двумя членами ОДКБ. Еще одно требование - чтобы коллективные силы не направлялись в другие государства, если это противоречит национальному законодательству. Такие ограничения есть уУзбекистана и Белоруссии. Также Ташкент настаивает, чтобы соглашение о КСОР вступило в силу не после его подписания, а только после ратификации парламентами стран-участниц. Отдельные вопросы к соглашению остаются у Армении, которую волнует использование войск ОДКБ в случае потенциального конфликта с Азербайджаном.

В РАМКАХ СОТРУДНИЧЕСТВА в сфере 6езопасности с государствами Центральной Азии Россия стремится выработать долгосрочную стратегию, соответствующую ее военной доктрине и концепции национальной безопасности. В практической реализации этой стратегии важно не только наметить наиболее важные векторы, но и четко определить соответствующие ресурсы, способные с наименьшими потерями для нашей экономики укрепить позиции России в этом жизненно важном регионе.

В последние два-три года российское политическое руководство прилагает целенаправленные усилия как в двустороннем, так и в многостороннем формате с тем, чтобы максимально снизить уровень

\section{Ключевые слова}

Казахстан, Узбекистан, Туркменистан, Киргизстан, Таджикистан, ОДКБ, КСОР постоянной внутрирегиональной напряженности, выступая посредником во многих болезненных вопросах, в том числе в области энергообеспечения и водопользования. Однако в силу практической неразрешимости указанных проблем наши усилия не приносят желаемых результатов.

Отрицательно сказывается на наших успехах и стремительный рост влияния как региональных (Китай, Япония, Индия), так и внерегиональных акторов (США, Евросоюз).

Отработка взаимодействия с другими внешними акторами и создаваемыми ими в регионе институциональными структурами становится задачей номер один. Сложность ее решения в том, что, с одной стороны, эти структуры разрушают постсоветское пространство, создавая иные интеграционные векторы, а, с другой - они могут частично служить целям стабилизации региона, что отвечает интересам России ${ }^{11}$.

Не менее важным является поиск ответа на риторический вопрос - готова ли Россия вновь вкладывать в регион столь же крупные средства, как в советский период, и какова будет эффективность этих инвестиций? Ведь сложившаяся в некоторых центральноазиатских странах политическая система способна поглотить и потратить «нецелевым» образом очень большие средства внешних спонсоров, направленных на реализацию тех или иных проектов развития. Иными словами, целесообразно ли достижение поставленных российской стороной политических целей ценой очередного напряжения нашей собственной экономики?

Однако самая главная задача сегодня - обеспечить практическую реализацию подписанных в дека6ре 2009 г. договоренностей в рамках ЕврАзЭС о запуске таможенного союза. Успех в экономической области, затрагивающей интересы миллионов граждан Белоруссии, Казахстана и России, способен, на наш взгляд, значительно укрепить российские позиции в регионе и, наряду с сотрудничеством в военно-политической сфере, обеспечить достойное место Российской Федерации в Центральной Азии.

Stanislav I. Cherniyavsky. Contribution of Russia to regional cooperation in the sphere of security in Central Asia

The article evaluates military and political cooperation between Russia and Central Asia States on the bilateral level as well as in the frame of Collective Security Treaty Organization (CSTO).

\section{Keywords}

Kazakhstan, Uzbekistan, Turkmenistan, Kyrgyzstan, Tajikistan, Collective Security Treaty Organization (CSTO), Collective Rapid Reaction Force (KSOR) 
Чернявский С.И.

1. Чернявский С.И. Политика России в Центральной Азии и Закавказье в 1992-2002 гг. // Южный фланг СНГ. Центральная Азия - Каспий - Кавказ: возможности и вызовы для России. М., 2008. С. 50-54.

2. Казанчев А.А. «Большая игра» с неизвестными правилами: мировая политика и Центральная Азия. М., 2008. С. 153-154.

3. Лаумулин М. Геополитические ориентиры стран Центральной Азии на современном этапе // Центральная Азия и Кавказ. 2008. № 5 . С. 21.

4. См. «Годы, которые изменили Центральную Азию». М.: Центр стратегических и политических исследований, Институт Востоковедения РАН, 2009.

5. См. подробнее: Социальная специфика развития политической культуры в Центральной Азии: Материалы международной конференции в Душанбе, 16-17 января 2009 г. Центр стратегических и политических исследований (Москва), Центр стратегических и политических исследований при Президенте РТ (Душанбе), Фонд Розы Люксембург (ФРГ). М., 2009.

6. Князев А.А. Киргизия и Россия: безопасность, сотрудничество и перспективы развития в центральноазиатском контексте. Информационно-аналитический портал «Евразийский дом». 7.03.2008.

7. Парамонов В., Столповский О. Россия и страны Центральной Азии: двустороннее сотрудничество в сфере безопасности // Центральная Азия и Кавказ. 2009. № 2. С. 63.

8. Старчак М. СШA VS Россия в попытке сотрудничества с Туркменистаном в сфере безопасности и обороны // Центральная Азия и Кавказ. 2009. № 2. С. 98.

9. Абдувалиева Р. Проблемы безопасности Кыргызстана на современном этапе // Центральная Азия и Кавказ. 20о9. № 2. С. 8586.

10. Никитина Ю.А. Вклад ОДКБ в региональное сотрудничество в сфере безопасности // Аналитические записки НКСМИ МГИМО (У) МИД РФ. Май 2009. Вып. 3(43).

11. Морозов Ю., Макдермотт Р. Перспективы сотрудничества организаций и союзов в целях обеспечения стабильности и безопасности в центральноазиатском регионе. Взгляд из Москвы и Лондона // Центральная Азия и Кавказ. 20о8. № 6. С. 32. 